JRKA Volume 2 Isue 2, Februari 2016: 1 - 12

\title{
ANALISA PENGARUH LABA BERSIH DAN ARUS KAS TERHADAP RETURN SAHAM PADA PERUSAHAAN FOOD AND BEVERAGES: STUDI EMPIRIS DI BURSA EFEK INDONESIA
}

\author{
Haryatih Se., M.Si \\ Universitas Budi Luhur
}

\begin{abstract}
Target of this research to test influence of net income and cash flow to stock returns of at Food and Bevarages Companys: empirical study in effect exchange Indonesia. Variable used by as much 5 consisted of by 4 independent variable and 1 variable dependen. 4 independent variable that is net income, cash flow operate for, cash flow investment, and the cash flow financing. While 1 variable of dependen that is stock returns.

This research test 10 Food and Bevarages Companys which have been enlisted in effect echange of Indonesia and have published financial statement which have been made an audit of by 31 December 2012 - 2015 representing the part of consideration of at determination of sampel by using purposive sampling. Statistical methods used by is doubled linear regression by using tes- $t$ and tes $\mathrm{F}$ of at storey level of signifikansi $5 \%$.

Result of research individually prove that net income and cash flow operating have an effect to return share. While together is net income, cash flow operate for, cash flow investment, and cash flow of financing have an effect on positive to stock returns. This matter show indication that stock returns of influenced by Food and Beverage Company emiten of existence of publicing it the financial statement specially which deal with information of performance of company of found on income statement and cash flow statement.

Keyword : Income statement, Cash flow statement, Stock returns.
\end{abstract}

PENDAHULUAN

Fokus utama pelaporan keuangan adalah informasi mengenai laba dan komponennya. Laba merupakan salah satu parameter kinerja perusahaan yang mendapat perhatian utama dari investor. Pentingnya informasi laba secara tegas telah dinyatkan dalam Statement of Financial Accounting Concepts (SFAC) No.1, bahwa selain untuk menilai kinerja manajemen, juga membantu mengestimasi kemampuan laba yang representatif, serta untuk menaksir risiko dalam berinvestasi.

Selain laba, investor juga menggunakan informasi yang berkaitan dengan penerimaan dan pengeluaran kas yang lebih mencerminkan likuiditas. Informasi ini dapat ditemukan dalam laporan arus kas yang sudah menjadi 
bagian integral dari laporan keuangan perusahaan publik dalam Pernyataan Standar Akuntansi Keuangan No. 2 tahun 2015.

Dengan adanya, informasi laporan keuangan perusahaan tersebut, maka investor akan mengetahui kondisi keuangan suatu perusahaan dan mengetahui bagaimana perkembangannya dari tahun ke tahun. Hal tersebut membuat peerusahaan ingin menampilkan laporan keuangannya sebaik mungkin untuk mendapatkan penilaian positif dari pengguna laporan keuangan, termasuk investor. Pertimbangan investor dalam membuat keputusan dapat mempengaruhi reaksi pasar yang antara lain terlihat padsa tingkat keuntungan (return) saham.

Banyak penelitian yang berkaitan laporan laba rugi dan laporan arus kas yang dapat mempengaruhi kepercayaan investor dalam mengambil keputusan investasi, yaitu penelitian yang dilakukan oleh Parawiyati dan Zaki Baridwan (1998) melakukan penelitian untuk menganalisa kemampuan laba dan arus kas di masa mendatang. Hasil penelitian mereka membuktikan bahwa laba dan arus kas periode yang lalu mempunyai manfaat untuk memprediksi laba dan arus kas di masa mendatang. Penelitian yang dilakukan oleh Nur Fadjrih Asyik (1998) untuk penelitian tambahan kandungan informasi arus kas yang menyimpulkan bahwa laporan arus kas dari aktivitas operasi, investasi, dan pendanaan memberikan informasi yang bermanfaat bagi investor. Januar Eko Prasetio (2003) menguji interaksi laba dengan laporan arus kas terhadap return saham dengan kurun waktu selama tiga tahun, menyimpulkan bahwa interaksi laba dan arus kas operasi berpengaruh signifikan terhadap return saham sedangkan arus kas investasi dan arus kas pendanaan tidak berpengaruh signifikan terhadap return saham. Selanjut terdapat beberapa penelitian yang melakukan penelitian yang sama diantaranya Evi Mutia (2012), Nico Alexander dan Nicken Destriana (2013), A.A. Istri Raissa Wulandari dan I Gusti Ayu Made Asri Dwija Putri (2014), dan Gd Gilang Gunandi dan I Ketut Wijaya Kesuma (2015), memberikan kesimpulaan yang sama bahwa laba akuntansi dan arus kas berpengaruh signifikan terhadap return saham.

Penelitian lainnya, Azilia Yocelyn dan Yulius Jogi Christiawan (2012) menyimpulkan bahwa pengungkapan laba akuntansi berpengaruh signifikanterhadap return saham. Hal ini menandakan bahwa investor mempertimbangkan informasi laba akuntansi yang diungkapkan dalam laporan tahunannya untuk membuat keputusan. Sedangkan variabel bebas yang lainnya tidak terbukti secara signifikan berhubungan dengan return saham. Sedangkan penelitian yang dilakukan oleh Ni Putu Putriani dan I Made Sukartha (2014) menguji arus kas 
operasi dan laba bersih menyimpulkan bahwa arus kas operasi tidak berpengaruh secara signifikan pada return saham, sedangkan laba bersih memiliki pengaruh yang positif dan signifikan pada return saham

Penelitian ini mengembangkan penelitian yang dilakukan Putu Putriani dan I Made Sukartha (2014) dengan menambahkan arus investasi dan arus kas pendanaan sebagai variabel indepeden dan menerapkan untuk menguji laba bersih, arus kas operasi, arus kas investasi, dan arus kas pendanaan sebagai variabel independen terhadap return saham (variabel dependen) seperti yang dilakukan Azilia Yocelyn dan Yulius Jogi Christiawan (2012). Peneliti akan menguji laba bersih, arus kas operasi, arus kas investasi, dan arus kas pendanaan terhadap return saham pada Perusahan Manufaktur spesifik yaitu Perusahan Food and Beverage dengan kurun waktu lima tahun 2010 - 2015. Perusahaaan yang bergerak pada sektor food and beverages ini merupakan perusahaan yang memproduksi makanan dan minuman yang saat ini sangat dibutuhkan, karena produk makanan dan minuman tetap menjadi kebutuhan utama masyarakat. Berdasarkan evaluasi tersebut maka dapat dilakukan penelitian dengan judul "Analisa Pengaruh Laba Bersih dan Arus Kas Terhadap Return Saham Pada Perusahaan Food and
Beverages: Studi Empiris di Bursa Efek Indonesia".

\section{TINJAUAN PUSTAKA}

\section{Laba}

Laba menurut sofyan Syafri Harahap (1999: 147), merupakan perbedaan antara revenue yang direalisasi timbul dari transaksi pada periode tertentu dihadapkan dengan biaya-biaya yang dikeluarkan pada periode tersebut. Selanjutnya menurut Hans Kartikahadi dan dkk (2012:180) laba adalah untuk memberikan informasi tentang kinerja keuangan entitas selama suatu periode usaha tertentu

\section{Arus Kas}

Menurut pernyataan Standar Akuntansi Keuangan (PSAK) No.2, laporan arus kas merupakan bagian yang tidak terpisahkan (integral) dari laporan keuangan, dengan tujuan untuk mengisi kesenjangan informasi dari Laporan Neraca, Laporan Rugi Laba, dan Laporan Laba ditahan yaitu dalam hal menilai kemampuan perusahaan dalam menghasilkan kas dan setara kas serta kebutuhan perusahaan untuk menggunakan kas. Menurut Henry Simamoru (2002:488) tujuan utama arus kas adalah menyediakan informasi tentang penerimaan-penerimaan kas dan pembayaran serta pendanaan dari suatu entitas selama periode tertentu. Selain itu, laporan arus kas dapat memasok informasi yang memungkinkan para 
pemakai untuk mengevaluasi perubahan dalam aktiva bersih perusahaan, sttruktur keuangan (termasuk likuiditas dan solvabilitas), dan kemampuan untuk mempengaruhi jumlah serta waktu arus kas dalam rangka adaptasi dengan perubahan keadaan dan peluang bisnis. Selanjutnya menurut Hans Kartikahadi dan dkk (2012:216) laporan arus kas di susun untuk menjelaskan (a) jumlah penerimaan dan pengeluaran dana (kas dan setara kas) selama suatu periode usaha, (b) sumber penerimaan dan sasaran pengeluaran, serta (c) bertambah atau berkurangnya saldo akhir kas dan setara kas dibandingkan saldo awal periode usaha.

\section{Return Saham}

Return saham merupakan hasil atau keuntungan yang diperoleh dari pemegang saham sebagai hasil dari investasinya. Fakhrudin dan sopian Handianto (2000:25) membedakan return dapat berupa return realisasi atau yang sudah terjadi dan return ekspektasi atau yang belum terjadi tetapi diharapkan akan terjadi di masa mendatang. Untuk menghitung berapa tingkat return yang dihasilkan dari investasi yang ditanam,dapat menggunakan perhitungan Geometric Mean.Geometric Mean (GM) adalah metode perhitungan rata-rata return terhadap perbandingan harga saham pada saat $t$ dan harga saham $t-1$ sehingga dapat memperhitungkan compounding 4 return dari investasi tersebut. Harga suatu saham pada hakikatnya ditentukan oleh kekuatan penawaran dan permintaan terhadap saham yang bersangkutan. Kedua kekuatan itu sendiri merupakan pencerminan dari ekpektasi pemodal terhadap kinerja saham di masa yang akan datang (Ajie 2003) dalam Azilia Yocelyn dan Yulius Jogi Christiawan (2012: 83)

\section{METODOLOGI PENELITIAN}

\section{Ruang Lingkup Penelitian}

Lokasi penelitian yang diteliti adalah perusahaan Go Public di Bursa Efek Indonesia. Penulis meneliti 9 emiten Perusahaan Food and Beverage dengan menggunakan data tahun 2010 sampai dengan tahun 2015. Ruang lingkup dari penelitian ini membahas pengaruh antara variabel bebas (independent variable) terdiri atas laba bersih (X1), arus kas operasi (x2), arus kas investasi (X3), dan arus kas pendanaan (X4), terhadap variabel bebas (dependent variable) yaitu return saham (Y).

\section{Metode Penentuan Sampel}

Penulis menentukan sampel dengan menggunakan metode judgement sampling atau purposive sampling. Pada Purposive sampling ini, peneliti mengumpulkan data atas dasar pertimbangan:

1. Perusahaan Food and Beverage yang terdaftar di Bursa Efek Indonesia 
2. selama tahun 2010 sampai dengan 2015.

3. Perusahaan yang mempublikasikan laporan keuangan tahunan secara konsisten mulai dari tahun 2010 sampai dengan 2015.

4. Perusahaan yang menggunakan periode laporan keuangan per 31 Desember.
5. Saham emiten yang aktif diperdagangkan di BEI.

Berdasarkan kriteria yang telah ditentukan maka diperoleh 9 emiten Food and Beverage tiap tahun yang dapat dijadikan sampel penelitian selama tahun 2010 sampai dengan tahun 2015 disajikan pada tabel 1 .

Tabel 1

Prosedur Pemilihan Sampel

\begin{tabular}{|l|c|}
\hline Keterangan & $\begin{array}{l}\text { Jumlah } \\
\text { Perusahaan }\end{array}$ \\
\hline Jumlah perusahan Food and Beverages di BEI 31 Desember 2010 & 15 \\
Perusahaan Food and Beverages yang tidak termasuk sampel: & \\
- Saham tidak aktif diperdagangkan & $(2)$ \\
- Data tidak tersedia dan tidak lengkap & $\underline{(4)}$ \\
Jumlah perusahaan yang terpilih sebagai sampel & $\mathbf{9}$ \\
\hline
\end{tabular}

Metode Pengumpulan data

Metode pengumpulan data yang digunakan dalam penelitian ini adalah: penelitian kepustakaan (Library Research). Dimana sumber informasi ini dimaksudkan sebagai landasan teoritis untuk menganalisa dan membahas permasalahan penelitian tersebut.

\section{Batasan Operasional Variabel}

Definisi variabel operasional yang dimaksudkan untuk memberikan pedoman arahan atau petunjuk pada pelaksanaan pengukuran suatu variabel supaya dicapai pengukuran yang objektif, valid, dan relibel. Dalam penelitian ini variabel operasional yang akan diteliti dibatasi sebagai berikut:

1. Laba bersih

2. Arus kas operasi

3. Arus kas investasi

4. Arus kas pendanaan

5. Return saham

Teknik Analisis

Penelitian mengunakan teknik analis yang bersifat kuantitatif, rincian sebagai berikut:

1. Menghitung Retun Saham M.Fakhruddin dan M.Sopian Hadianto, 2001)

$$
R_{t}=\frac{P_{t}-P_{t-1}}{P_{t-1}}
$$


Dimana:

$\mathrm{R}_{\mathrm{t}}=\underset{\text { diharapkan) }}{\text { return }}$ sesungguhnya (yang menunjukkan periode waktu tertentu pada masa lalu (yang akan datang).

$\mathrm{P}_{\mathrm{t}}=$ harga saham pada periode waktu t (periode awal)

$\mathrm{P}_{\mathrm{t}-1}=$ harga saham pada periode waktu t-1 (periode akhir)

2. Regresi Linier Berganda

$Y=a+b_{1} X_{1}+b_{2} X_{2}+b_{3} X_{3}+b_{4} X_{4+} \varepsilon$

Dimana:

$\mathrm{Y}=$ return saham $(\mathrm{RT})$

$\mathrm{a}=$ intercept (titik potong)

$\mathrm{b}=$ koefiseinsi regresi (slope)

$\mathrm{X}_{1}=$ laba bersih (LB)

$\mathrm{X}_{2}=$ arus kas operasi (AKO)

$\mathrm{X}_{3}=$ arus kas investasi (AKI)

$\mathrm{X}_{4}=$ arus kas pendanaan (AKP)

\section{Pengujian Bagi Kelinearan dan} Koefisien Regresi

Regresi berganda menggunakan dua pengujian yaitu uji kelinearan (Uji F/Uji simultan) dan uji koefisien regresi (Uji t/ Uji parsial). Untuk menguji Hipotesa Ho = $\mathrm{b} 1=\mathrm{b} 2=\mathrm{b} 3=\mathrm{b} 4=0 \quad$ dan $\mathrm{Ha}$ $=\mathrm{b} 1=\mathrm{b} 2=\mathrm{b} 3=\mathrm{b} 4 \neq 0$

Langkah-langkah yang digunakan untuk menguji hipotesa sebagai berikut:

1. Menentukan Ho dan Ha

2. Menentukan level of significance $5 \%$
3. Menentukan nilai $\mathrm{F}$ (F hitung) dan nilai $\mathrm{t}$ ( $\mathrm{t}$ hitung) dari sampel

4. Menentukan Kriteria penerimaan dan penolakan Ho.

Jika probabilitas $>0,05 \rightarrow$ terima Ho

Jika probalitasn $<0,05 \rightarrow$ tolak Ho

5. Sebelum pengujian hipotesis, juga diuji apakah terdapat penyimpangan asumsi klasik, diantaranya: Multikolinearitas, Heterokesdatisitas, Normalitas, dan Autokorelasi.

Dalam penelitian ini regresi linear berganda dan pengujian bagi kelinearan dan koefisian regresi dilakukan dengan menggunakan komputer program SPSS for windows 7.5 sehingga tidak perlu melihat tabel, langsung dapat dilihat nilai signifikansinya.

\section{HASIL DAN PEMBAHASAN}

\section{Uji Asumsi Klasik Regresi}

Sebelum melakukan analisis regrtesi berganda terhadap data yang diperoleh dalam penelitian, terlebih dahulu dilakukan pengujian terhadap persyaratan-persyaratan klasik regresi berganda, yaitu:

\section{1) Multikolinearitas}

Multikolinearitas bertujuan untuk menguji apakah model regresi ditemukan aadanya korelasi antara variabel bebas. Dari hasil uji multikolinearitas berdasarkan besaran tolerance dan VIF, terlihat bahwa angka tolerance berkisar antara 0,143 
hingga 0,365 atau tidak kurang dari angka 0,1 . Demikian pula dengan besaran VIF, pada umumnya berkisar antara 2,733 hingga 7,009 atau tidak kurang dari angka 10. Angka-angka tolerance dan VIF tersebut menunjukkan bahwa tidak terdapat multikolinearitas antara variabel independen. Dengan demikian dapat disimpulkan bahwa berdasarkan tolerance dan VIF, model regresi ini layak dipakai dalam pengujian (Sunjoyo dkk., 2013).

\section{2) Heterokesdatisitas}

Heterokesdatisitas bertujuan menguji apakah dalam model regresi terjadi ketidaksamaan variance dari residual satu pengamatan ke pengamatan yang lain. Dari gambar berupa grafik terlihat titik menyebar secara acak, tidak membentuk sebuah pola tertentu yang jelas, serta tersebar baik diatas maupun dibawah 0 pada sumbu $Y$. Hal ini berarti tidak terjadi heterokesdatisitas pada model regresi, sehingga model regresi layak dipakai untuk prediksi return saham berdasarkan masukan variabelvariabel independent-nya.

\section{3) Normalitas}

Normalitas bertujuan untuk menguji apakah dalam model regresi, variabel depedent, variabel independent atau keduanya mempunyai distribusi normal ataukah tidak. Model regresi yang baik adalah distribusi data normal atau mendekati normal. Hasil uji normalitas berupa grafik terlihat titik-titik menyebar diseluruh grafik diagonal, serta penyebaran mengikuti arah garis diagonal, maka model regresi layak dipakai untuk memprediksi return saham berdasarkan masukan variabelvariabel independent-nya.

\section{4) Autokorelasi}

Autokorelasi bertujuan untuk menguji apakah dalam sebuah model regresi linier ada korelasi antara kesalahan pengganggu pada periode $\mathrm{t}$ dengan kesalahan pada periode $\mathrm{t}-1$ (sebelumnya). Jika terjadi korelasi, maka dinamakan ada problem autokorelasi. Tentu saja model regresi yang baik adalah regresi yang bebas dari autokorelasi. Hasil uji autokorelasi pada model summary terlihat angka D-W sebesar +1.591 . Hal ini berarti model regresi diatas tidak terdapat masalah autokorelasi. Dikaitkan dengan pengujian yang dilakukan Durbin-Watson, angka D$\mathrm{W}$ di antara -2 sampai +2 , berarti tidak ada autokorelasi.

\section{Uji Regresi Berganda}

Uji asumsi klasik dilakukan terlebih dahulu untuk mengetahui apakah model regresi dalam penelitian ini dapat layak digunakan. Setelah lolos dalam uji asumsi klasik, selanjutnya dilakukan analisis regresi linear berganda, yang hasilnya tersaji dalam Tabel 2. 
Tabel 2.

Hasil Analisis Regresi Linear Berganda

\begin{tabular}{|c|c|c|c|c|c|}
\hline \multirow[t]{2}{*}{ Variabel } & \multicolumn{2}{|c|}{ Unstandardized Coefficient } & \multirow{2}{*}{$\begin{array}{c}\begin{array}{c}\text { Standardized } \\
\text { Coefficients }\end{array} \\
\text { Beta } \\
\end{array}$} & \multirow[b]{2}{*}{$\mathrm{t}$} & \multirow[b]{2}{*}{ Sig. } \\
\hline & B & Std. Error & & & \\
\hline (Constant) & .005 & .006 & & .795 & .431 \\
\hline LB & $2.998 \mathrm{E}-19$ & .000 & .807 & 3.185 & .003 \\
\hline AKO & $-1.834 \mathrm{E}-19$ & .000 & -.726 & -2.113 & .040 \\
\hline AKI & $-3.791 E-20$ & .000 & -.125 & -.438 & .663 \\
\hline AKP & $-4.914 \mathrm{E}-20$ & .000 & -.108 & -.503 & 617 \\
\hline Adjusted $\mathrm{R}^{2}$ & & & & & 0.109 \\
\hline F Hitung & & & & & 2.618 \\
\hline Sig. $\mathrm{F}$ & & & & & 0.046 \\
\hline
\end{tabular}

Sumber: Data dioleh peneliti, 2016

Berdasarkan hasil olahan SPSS dari Tabel 2 maka dapat dibuat model regresinya sebagai berikut:

$\mathrm{RT}=0.005+2.998 \mathrm{E}-19 \mathrm{LB}-$ 1.834E-19 AKO - 3.791E-20 AKI -4.914E-20 AKP

Uji $F$, dimana didapati peubah bebas (LB, AKO, AKI, dan AKP) dengan Adjusted $R$ Square $10.9 \%$ mempunyai kontribusi dalam menjelaskan peubah terikat return saham. Sisanya $89.1 \%$ peubah terikat dijelaskan oleh peubah-peubah lainnya yang tidak masuk lingkup penelitian ini dan Standar Error of Estimate (SEE) adalah 0,03828. Makin kecil SEE akan membuat model regresi semakin tepat dalam memprediksi variabel dependent. Uji ANOVA didapati $\mathrm{F}$ hitung adalah 2,618 dengan tingkat signifikansi 0,046. Karena nilai probalitas $(0,046)$ jauh lebih kecil dari 0,05 maka Ho ditolak dan Ha diterima pada tingkat signifikansi alpha 5\% sehingga model regresi bisa dipakai untuk memprediksi Return Saham. Atau bisa dikatakan laba bersih (LB), Arus Kas Operasi (AKO), Arus Kas Investasi (AKI), dan Arus Kas Pendanaan (AKP) secara bersamasama berpengaruh terhadap Return Saham .

Sedangan uji t, didalam penelitian ini dilakukan pengujian terhadap pengaruh individual dari hasil regresi berganda untuk menguji hipotesis; (1) Ho:b1=0 (LB); (2) Ho:b2=0(AKO); (3) Ho:b3=0(AKI); dan (4) $\quad$ Ho;b4 $=0(A K P)$. Hasil pengolah data dengan SPSS menunjukkan bahwa kedua peubah bebas tidak signifikan pada tingkat 
signifikan alpha 5\% sehinggga tidak dapat menolak Ho untuk peubah bebas yang tidak diterima yaitu peubah AKI dan AKP masing-masing terhadap return saham, namun $\mathrm{LB}$ dan $\mathrm{AKO}$ yang mempunyai pengaruh signifikan terhadap return saham pada taraf signifikansi $95 \% \quad(0,05)$ dimana LB memiliki probabilitas $(0,003)$ lebih kecil 0,05 sehingga hipotesis Ho:b1 ditolak dan Ha:b1 diterima, dengan asumsi peubah bebas lainnya konstan. AKO memiliki probabilitas $(0,040)$ lebih kecil 0,05 sehingga hipotesis Ho:b2 ditolak dan Ha:b2 diterima, dengan asumsi peubah bebas lainnya konstan

\section{KESIMPULAN DAN IMPLIKASI}

Setelah dilakukan analisis deskriptif dan uji regresi (uji asumsi klasik regresi dan uji regresi berganda) maka dapat ditarik kesimpulan sebagai berikut:

1. Laba bersih berpengaruh secara signifikan terhadap return saham. Hasil penelitian ini konsisten dengan Januar Eko Prasetio (2003), Evi Mutia (2012), Nico Alexander dan Nicken Destriana (2013), A.A. Istri Raissa Wulandari dan I Gusti Ayu Made Asri Dwija Putri (2014), dan Gd Gilang Gunandi dan I Ketut Wijaya Kesuma (2015). Namun tidak konsisten dengan penelitian yang dilakukan Haris Kristanto dan Sumani (2015) membuktikan tidak terdapat pengaruh yang signifikan laba bersih terhadap return saham.

2. Arus kas operasi berpengaruh secara signifikan terhadap return saham. Hasil penelitian ini konsisten dengan penelitian Januar Eko Prasetio (2003) dan Nico Alexander dan Nicken Destriana (2013), membuktikan bahwa terdapat pengaruh yang signifikan arus kas operasi terhadap return saham. Namun tidak konsisten dengan penelitian yang dilakukan Dillah utami Cahyani (1999), Azilia Yocelyn dan Yulius Jogi Christiawan (2012), Evi Mutia (2012), Ni Putu Putriani dan I Made Sukartha (2014), serta Haris Kristanto dan Sumani (2015), membuktikan tidak terdapat pengaruh yang signifikan arus kas operasi terhadap return saham.

3. Arus kas investasi tidak berpengaruh secara signifikan terhadap return saham. Hasil penelitian ini konsisten dengan penelitian yang dilakukan Dillah utami Cahyani (1999), Januar Eko Presatio (2003), Azilia Yocelyn dan Yulius Jogi Christiawan (2012) membuktikan tidak terdapat pengaruh yang signifikan arus kas investasi terhadap return saham. Namun penelitian ini tidak konsisten dengan penelitian Evi Mutia (2012) membuktikan terdapat 
pengaruh yang signifikan arus kas investasi dengan return saham.

4. Arus kas pendanaan tidak berpengaruh secara signifikan terhadap return saham. Hasil penelitian ini konsisten dengan penelitian Dillah Utami cahyani (1999) dan Januar Eko Presatio (2003), Azilia Yocelyn dan Yulius Jogi Christiawan membuktikan tidak terdapat pengaruh yang signifikan arus kas pendanaan terhadap return saham.

5. Laba bersih, arus kas operasi, arus kas investasi, dan arus kas pendanaan secara bersama-sama berpengaruh signifikan terhadap return saham. Hasil penelitian ini ini konsisten dengan penelitian yang dilakukan Parawiyati dan Zaki Baridwan (1998) dan Nur Fadjrih Asyik (1998), Azilia Yocelyn dan Yulius Jogi Christiawan (2012) membuktikan bahwa laba bersih dan arus kas berpengaruh terhadap return saham sehingga dapat memberikan informasi yang bermanfaat bagi investor.

Hasil penelitian ini memberikan beberapa kontribusi potensial, pertama hasil penelitian ini akan memberikan input bagi pemakai laporan keuangan khususnya mengenai kemanfaatan laporan arus kas. Kedua menambah literature mengenai aspek fundamental yang berkaitan dengan kegunaan laporan keuangan, bahwa laporan arus kas dapat menambah informasi yang dihasilkan dari pelaporan keuangan, Ketiga bagi investor dengan mengetahui pengaruh yang signifikan arus kas investasi terhadap return saham, maka hasil penelitian ini dapat digunakan sebagai dasar pengambilan keputusan berinvestasi di Bursa Efek Indonesia.

Hasil penelitian ini mempunyai beberapa keterbatasan. Pertama, sampel yang digunakan dalam penelitian ini hanya perusahaan Food and Beverage sehingga penelitian ini tidak dapat digunakan sebagai dasar generalisasi. Kedua, penelitian ini tidak memasukkan faktor ekonomi yang kemungkinan akan mempengaruhi penelitian ini. Ketiga, keterbatasan waktu dan data dalam penelitian.

Penelitian berikutnya sebaiknya mempertimbangkan keterbatasan yang ada dalam penelitian ini. Penelitian berikutnya perlu mempertimbangkan penggunaan sampel secara keseluruhan yang terdaftar di Bursa Efek Indonesia. Penelitian berikutnya juga mempertimbangkan faktor ekonomi seperti kebijakan moneter pemerintah, tingkat suku bunga, inflasi, GDP, dan keputusan politik. Pengujian dengan pengamatan yang lebih lama mungkin akan meningkatkan hasil penelitian. 


\section{DAFTAR PUSTAKA}

A.A. Istri Raissa Wulandari dan I Gusti Ayu Made Asri Dwija Putri. 2014. Pengaruh Informasi Laba Akuntansi Dan Informasi Corporate Social Responsibility Pada Return Saham. E-Jurnal Akuntansi Universitas Udayana 7.2 Hlm: 462-476

Azilia Yocelyn dan Yulius Jogi Christiawan. 2012. Analisis Pengaruh Perubahan Arus Kas dan Laba Akuntansi Terhadap Return Saham pada Perusahaan Berkapitalisasi Besar. JURNAL AKUNTANSI DAN KEUANGAN, VOL. 14, NO. 2, NOVEMBER. Hlm:81-90

Apostulou, Nick dan Lawrence Crumbly.2003. Memahami Laporan dan Berita Keuangan. Bagian I, Penerjemah Sofyan Cikmat, Jakarta: PT. Elex Media Komputindo.

Evi Mutia. 2012. Pengaruh Informasi Laba Dan Arus Kas Terhadap Harga Saham. Jurnal Akuntansi, Vol. 1, No. 1, Oktober. Hlm: 12-22

Fakhruddin dan Sopian Hadianto.2001. Perangkat dan Model Analis Investasi di Pasar Modal. Buku I, Jakarta: PT. Elex Media Komputindo.

Gd Gilang Gunandi dan I Ketut Wijaya Kesuma. 2015. Pengaruh ROA, DER, EPS Terhadap Return Saham Perusahaan Food And Beverage BEI. E-Jurnal Manajemen Unud. Vol. 4. No. 6. Hlm: 1636-1647
Gill, James O dan Moiro Chatton. 2003. Memahami Laporan Keuangan. Penerjemah Dwi Prabaningtyas, Jakarta: PPM.

Haris Kristanto dan Sumani. 2015. Pengaruh Perubahan Arus Kas Operasi, Laba Akuntansi, Suku Bunga, Dan Inflasi Terhadap Return Saham. Banking and Management. Review Vol 4. No 2. Hlm: 522-539

Hendriksen, Eldon. 1999. Teori Akuntansi. Edisi Keempat, Jilid I, Penerjemah Wim Liyono, Jakarta: Erlangga.

Husnan, Suad. 1993. Dasar Teori Portofolio dan Analisis Sekuritis. Edisi kedua, Yogyakarta: UPP AMP YKPN.

Ikatan Akuntansi Indonesia. 2015. Standar Akuntansi Keuangan. Jakarta: Salemba Empat.

Kartikahadi dan dkk. 2012. Akuntansi Keuangan Berdasarkan SAK Berbasis IFRS. Jakarta: Salemba Empat.

Kieso, Donald E, Weygandt, Jerry J \& Paul D Kimmel. 2012. Accounting Principle, IFRS Edition. Willey Plus

Nico Alexander dan Nicken Destriana. 2013. Pengaruh Kinerja Keuangan Terhadap Return Saham. Jurnal Bisnis dan Akuntansi. Vol.15. No.2. Desember. Hlm: 123-132

Ni Putu Putriani dan I Made Sukartha. 2014. Pengaruh Arus Kas Bebas Dan Laba Bersih Pada Return Saham Perusahaan Lq-45. E-Jurnal Akuntansi Universitas Udayana 6.3. Hlm: 390-401 
Niswonger, dkk. 1999. Prinsip-Prinsip Akuntansi. Edisi 19, jilid I, Penerjemah Alfonsus Sirait dan Helda Gunawan, Jakarta: Erlangga.

Asyik, Nur Fadjrih.1999. Tambahan

Kandungan Informasi Arus Kas.

Jurnal Riset Akuntansi Indonesia

Volume 2 No 2, Juli 1999.

Parawiyati dan Zaki baridwan. 1998.

Kemampuan Laba dan Arus AKs

Perusahaan Go Public di Indonesia. Jurnal Riset Akuntansi Indonesia Volume I No I, Januari.

Prasetio, Januar Eko.2003. Analisa

Pengaruh Interaksi Laba Dengan Laporan Arus Kas Terhadap Return Saham. Jurnal Wahana Volume 6 No I, Februari.

Santoso, Singgih. 2000. Buku Latihan SPSS Statisitik Parametrik. Jakarta: PT. Elex Medika Komputindo.

Simamora, Henry. 2002. Akuntansi

Basis Pengambilan Keputusan Bisnis. Jakarta: Salemba Empat.

Syafri Harahap, Sofyan. 2002. Teori Akuntasi Laporan Keuangan. Jakarta: PT. Bumi Aksara, 2002.

Sunjoyo., Setiawan, R., Carolina, V., Magdalena, N., dan Kurniawan, A. 2013. Aplikasi SPSS untuk SMART Riset. Bandung: Alfabeta. Utami Cahyani, Dillah. 1999. Muatan Informasi Tambahan Arus Kas Dari Aktivitas Operasi, Investasi dan Pendanaan. Jurnal Bisnis dan Akuntansi Vol. I No.I, April.

Wibowo dan Abu Bakar Arif. 2002.

Pengantar Akuntansi II. Jakarta:

Grasindo.

www.idx.co.id 